Research Article

\title{
Triterpenoids from the Leaves of Centella asiatica Inhibit Ionizing Radiation-Induced Migration and Invasion of Human Lung Cancer Cells
}

\author{
Ah-Reum Han, ${ }^{1}$ Sanghun Lee, ${ }^{2}$ Sujin Han, ${ }^{3}$ Yeon Jin Lee, ${ }^{3}$ Jin-Baek Kim, ${ }^{1}$ \\ Eun Kyoung Seo $\mathbb{1}{ }^{3}$, and Chan-Hun Jung $\mathbb{1}^{4}$ \\ ${ }^{1}$ Advanced Radiation Technology Institute, Korea Atomic Energy Research Institute, Jeongeup-si, Jeollabuk-do 56212, \\ Republic of Korea \\ ${ }^{2}$ Jaseng Spine and Joint Research Institute, Jaseng Medical Foundation, Seoul 06110, Republic of Korea \\ ${ }^{3}$ College of Pharmacy, Graduate School of Pharmaceutical Sciences, Ewha Womans University, Seoul 03760, Republic of Korea \\ ${ }^{4}$ Jeonju AgroBio-Materials Institute, Jeonju-si, Jeollabuk-do 54810, Republic of Korea
}

Correspondence should be addressed to Eun Kyoung Seo; yuny@ewha.ac.kr and Chan-Hun Jung; biohun@gmail.com

Received 16 March 2020; Revised 4 September 2020; Accepted 8 September 2020; Published 24 September 2020

Academic Editor: Victor Kuete

Copyright (c) 2020 Ah-Reum Han et al. This is an open access article distributed under the Creative Commons Attribution License, which permits unrestricted use, distribution, and reproduction in any medium, provided the original work is properly cited.

Radiotherapy using ionizing radiation is a major therapeutic modality for advanced human lung cancers. However, ionizing radiation itself can induce malignant behaviors such as cancer cell migration and invasion, leading to local recurrence or distal metastasis. Therefore, safer and more effective agents that inhibit the metastatic behaviors of cancer cells in radiotherapy are needed. As a part of our ongoing search for new radiotherapy enhancers from medicinal herbs, we isolated the following triterpenoids from the ethanol extract of Centella asiatica: asiatic acid (1), madecassic acid (2), and asiaticoside (3). These compounds inhibited the ionizing radiation-induced migration and invasion of A549 human lung cancer cells at noncytotoxic concentrations. These results suggest that triterpenoids 1-3 isolated from C. asiatica are candidate natural compounds to enhance the effect of radiotherapy in patients with non-small-cell lung cancer.

\section{Introduction}

Centella asiatica (family Apiaceae), commonly known as Indian Pennywort, is an ethnomedical plant that is widely used in India for treating skin problems and for revitalizing the brain and nervous system [1]. It has been reported to have various pharmacological activities, including antioxidant, anti-inflammatory, anticancer, neuroprotective, cardioprotective, skin protective, radioprotective, immunomodulatory, memoryenhancing, and wound-healing properties [2,3]. Studies on the chemical constituents of $C$. asiatica showed the presence of pentacyclic triterpenoids known as centelloids. These compounds are composed of terpene acids along with glycosides, including asiatic acid, asiaticoside, madecassic acid, madecassoside, brahmic acid, brahmoside, brahminoside, thankiniside, isothankunisode, madasiatic acid, centic acid, centelloside, and cenellic acid [4,5]. Asiatic acid and its derivatives possess a broad spectrum of pharmacological activities, such as anticancer [6-8], wound healing $[9,10]$, antiinflammatory $[10,11]$, antidiabetic [12], hepatoprotective $[13,14]$, and neuroprotective activities $[15,16]$. In addition, C. asiatica contains flavonoids, phenolic acids, and volatile oils, which exhibit antioxidant activity [17-19].

Lung cancer is the most common type of cancer and is associated with a high rate of cancer-related mortality worldwide [20]. Lung cancer is generally divided into two major subtypes: non-small-cell lung cancer (NSCLC) and small-cell lung cancer, accounting for $85 \%$ and $15 \%$ of all lung cancers, respectively [21]. More than $70 \%$ of patients with NSCLC are diagnosed at an advanced stage with metastatic disease (stage III or IV) [22]. Current treatment options for lung cancer include surgical resection, chemotherapy, and 
radiotherapy. However, for inoperable stage III and IV NSCLCs, radiotherapy and chemotherapy are considered the standard therapy [23]. Radiotherapy involves exposure to ionizing radiation (IR) to either directly or indirectly kill cancer cells, with the main advantage of localized application in most cases. However, IR can also promote malignant effects in some cases, such as local recurrence and distant metastasis [24]. IR at sublethal doses has been shown to promote cancer cell migration and invasion in various cancer cell lines [25, 26], and it induced metastasis in an animal model [27]. Furthermore, IR induces radioresistance, which contributes to the poor prognosis of patients with cancer, and it is the main reason for radiotherapy failure [28]. These effects can lead to tumor recurrence and metastases. Therefore, it is necessary to develop an effective and safe radiotherapy enhancer that can inhibit the induction of malignant behavior.

Although several studies have shown the anticancer effects of extracts and constituents from C. asiatica $[6-8,29]$, there has been no investigation on the inhibitory effects of C. asiatica components on IR-induced migration and invasion of cancer cells. Therefore, as a part of our ongoing search for new radiotherapy enhancers from medicinal herbs, we isolated three triterpenoids from the ethanol extract of C. asiatica and evaluated their inhibitory activities on the IR-induced migration and invasion of A549 human lung cancer cells.

\section{Materials and Methods}

2.1. Extraction and Isolation of Compounds from C. asiatica. The ethanol extract of $C$. asiatica (20 g; InterPharm Co., Seoul, Korea) was separated by silica gel thin-layer column chromatography (CC) using $\mathrm{CHCl}_{3}-\mathrm{MeOH}(1: 0$ to $0: 1, \mathrm{v} /$ $\mathrm{v})$ as a gradient solvent system with an RP-18 column (YMC gel ODS-A, $12 \mathrm{~nm}, \mathrm{~S}-150 \mu \mathrm{m}$; YMC Co., Japan), yielding fractions F1-F10. Fraction F2 (3g) was further subjected to silica gel CC using hexane-acetone ( $1: 0$ to $0: 1$, $\mathrm{v} / \mathrm{v})$ to afford subfractions F2.1-F2.7. Fraction F2.2 (1.2 g) was then subjected to reversed-phase $\mathrm{CC}$ with $\mathrm{MeOH}-\mathrm{H}_{2} \mathrm{O}$ $(1: 1$ to $0: 1, \mathrm{v} / \mathrm{v})$ as a solvent system to yield compound 1 $(532 \mathrm{mg})$. Fraction F2.5 (0.8 g) was purified by reversedphase CC with $\mathrm{CH}_{3} \mathrm{CN}-\mathrm{H}_{2} \mathrm{O}(3: 2$ to $1: 0$, v/v), resulting in the isolation of compound $2(258 \mathrm{mg})$. Fractions F8 and F9 $(3.2 \mathrm{~g})$ were combined and subjected to silica gel CC using gradient mixtures of $\mathrm{CHCl}_{3}-\mathrm{MeOH}-\mathrm{H}_{2} \mathrm{O}(7: 3: 0.3$ to $6: 4$ : $0.5, \mathrm{v} / \mathrm{v} / \mathrm{v})$ to obtain subfractions F8.1-F8.7. Fraction F8.5 $(1.0 \mathrm{~g})$ was chromatographed over ODS-A (120 g) using an isocratic solvent system of $\mathrm{MeOH}-\mathrm{H}_{2} \mathrm{O}(7: 3, \mathrm{v} / \mathrm{v})$ to yield compound 3 (351 mg). Thin-layer chromatographic analysis was performed on the Kieselgel $60 \mathrm{~F}_{254}$ (silica gel, 230-400 mesh, $0.25 \mathrm{~mm}$ layer thickness; Merck, Germany) and RP-18 $\mathrm{F}_{254 \mathrm{~s}}$ (Merck) plates, visualized under ultraviolet light $(254$ and $365 \mathrm{~nm})$ and $10 \%(\mathrm{v} / \mathrm{v})$ sulfuric acid spray, and then heated $\left(120^{\circ} \mathrm{C}, 5 \mathrm{~min}\right)$. The compounds were identified by one- and two-dimensional nuclear magnetic spectra recorded on a UNITY INOVA $400 \mathrm{MHz}$ FT-NMR instrument with tetramethylsilane as the internal standard. Optical rotations were measured on a JASCO P-2000 polarimeter.
2.2. Cell Culture. Human NSCLC cell line A549 was purchased from the Korean Cell Line Bank (Seoul, Korea). The cells were cultured in RPMI-1640 medium (Hyclone, Logan, UT, USA) supplemented with $10 \%$ fetal bovine serum (FBS; Hyclone) at $37^{\circ} \mathrm{C}$ in a $5 \% \mathrm{CO}_{2}$ incubator.

2.3. Cell Viability Assay. The Cell Counting Kit-8 (CCK-8) assay kit (Dojindo, Kumamoto, Japan) was used to evaluate cell viability according to the manufacturer's protocols. In brief, the cells were seeded in 96-well plates at a density of $2 \times 10^{3}$ cells/well and incubated at $37^{\circ} \mathrm{C}$ for $24 \mathrm{~h}$. The cultured cells were then treated with each compound at various concentrations $(0.78-200 \mu \mathrm{M})$. After 48 and $72 \mathrm{~h}$ of incubation, $10 \mu \mathrm{L}$ of CCK- 8 reagent was added to the cultured cells, which were then incubated for another $4 \mathrm{~h}$; the absorbance of the sample was measured at $450 \mathrm{~nm}$ on a VICTOR3 1420 Multilabel Counter (PerkinElmer, Waltham, MA, USA). The $50 \%$ inhibitory concentration $\left(\mathrm{IC}_{50}\right)$ was calculated from the dose-response curve using GraphPad software (GraphPad Software, La Jolla, CA, USA).

2.4. Wound-Healing Assay. Cell migration potential was evaluated using a wound-healing assay, as described previously [30]. In brief, the cells were seeded in a 24 -well plate $\left(3.5 \times 10^{5}\right.$ cells/well) containing plastic inserts (Cell Biolabs Inc., San Diego, CA, USA) for the generation of a wound field and incubated for $24 \mathrm{~h}$. After removing the inserts from the wells, the cells were exposed to 10 Gy $\gamma$-irradiation using a ${ }^{137} \mathrm{Cs} \gamma$-ray source (Atomic Energy of Canada, Mississauga, $\mathrm{ON}$, Canada) at a dose rate of $3 \mathrm{~Gy} / \mathrm{min}$. The irradiated cells were incubated with each compound at various concentrations $(2.5,5$, and $50 \mu \mathrm{M})$. Images were analyzed at 0 and $24 \mathrm{~h}$ using an AE31 microscope (Motic, Hong Kong).

2.5. Invasion Assay. Cell invasion potential was assessed using a transwell assay, as described previously [31]. In brief, IR-treated (10 Gy) or nontreated (0 Gy) A549 cells in serumfree medium were seeded $\left(1 \times 10^{4}\right.$ cells $)$ on the upper surface of Matrigel-coated transwell chambers (BD Biosciences). The lower compartments of the chambers were filled with medium supplemented with $10 \%$ FBS. After $16 \mathrm{~h}$ of incubation, the cells that invaded the lower surface of the filter were stained using the Diff-Quick Kit (Fisher Scientific) and counted under a microscope (Motic).

2.6. Statistical Analysis. All experiments were repeated at least three times. Statistical significance was determined using Student's $t$-test or one-way analysis of variance (GraphPad Software).

\section{Results and Discussion}

3.1. Isolation and Identification of Triterpenoids from the Ethanol Extract of C. asiatica. Medicinal herbs are a rich source of various bioactive compounds, which have long been used in the treatment of many diseases, including cancer [32]. Recently, compounds isolated from medicinal 


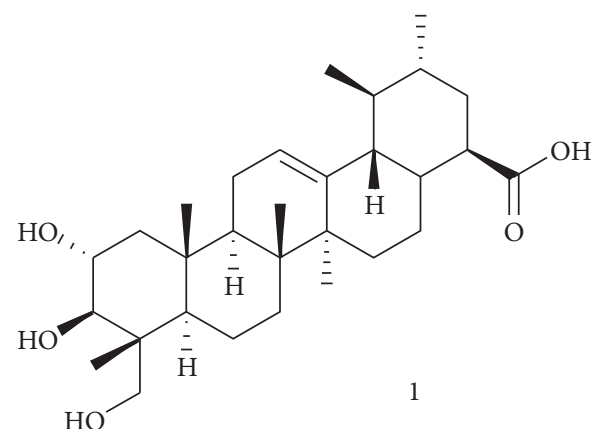

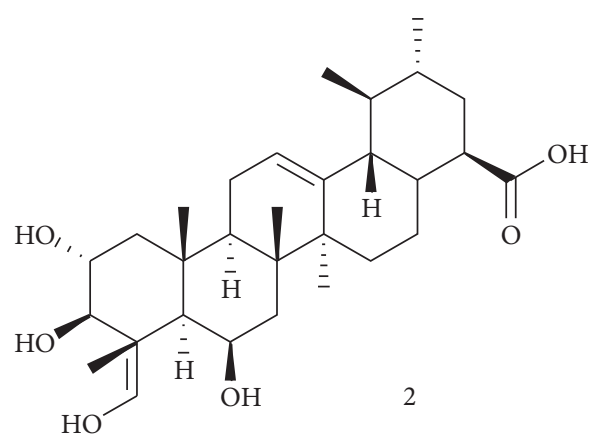

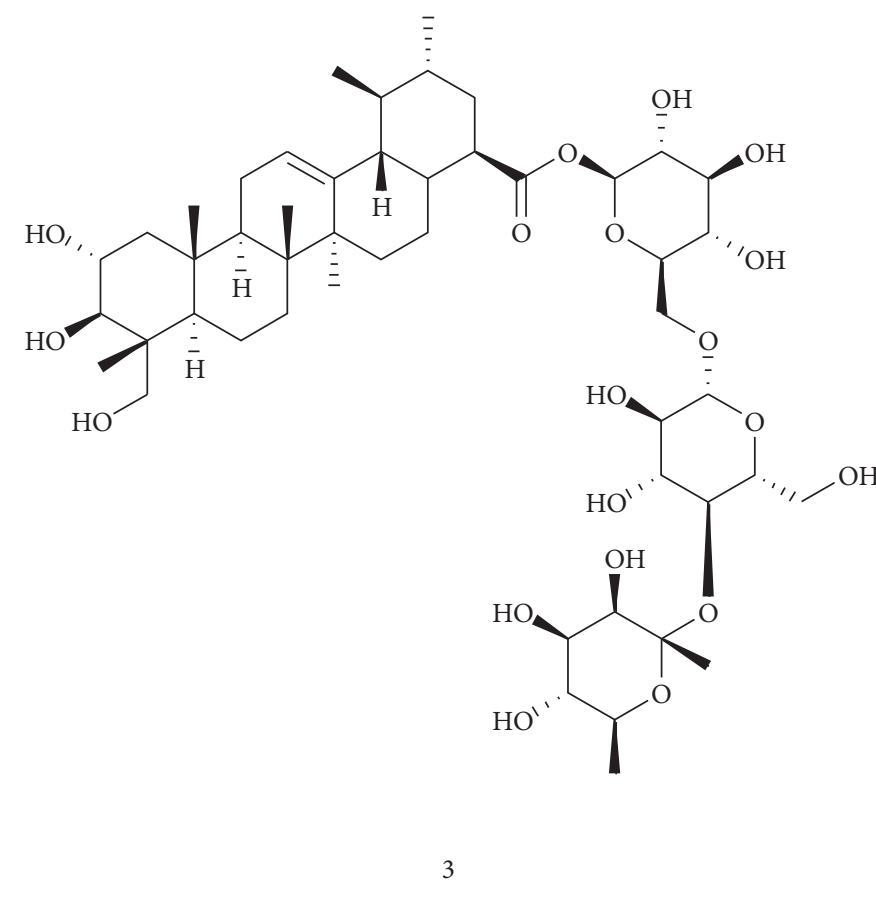

Figure 1: Chemical structure of compounds 1-3 isolated from Centella asiatica.

herbs have been identified as potent radiotherapy enhancers, such as radiosensitizers [33]. In this context, we have been searching for novel potent radiotherapy enhancers against IR-induced cancer cell migration and invasion from C. asiatica.

By chromatographic separation of the ethanol extract of C. asiatica, we isolated three compounds, which were identified as asiatic acid (1) [34], asiaticoside (3) [35], and madecassic acid (2) [36], by NMR spectra analysis and comparison with their published values (Figure 1).

Asiatic acid (1), asiaticoside (2), and madecassic acid (3) have been reported as the major components of $C$. asiatica [34-36], and these compounds have exhibited anticancer activity in various cancer cell lines. Asiatic acid has showed an antiproliferative effect by regulating apoptosis in a variety of human cancer cells, such as breast cancer, lung cancer, and melanoma cells [6]. Madecassic acid has also been found to inhibit cell growth by inducing apoptosis in mouse colon cancer cells and exhibit antiproliferative activities in various cancer cell lines via regulation of the ERK signaling pathway [7]. A recent study showed that the anticancer effect of asiaticoside is mediated by the inhibition of cell migration and invasion via the STAT3 signaling pathway in multiple myeloma [8]. However, the anticancer activity of these compounds in the context of their potential as radiotherapy enhancers has not been assessed.

3.2. Inhibitory Activities of Compounds 1-3 on IR-Induced Migration in A549 Cells. To search for potent radiotherapy enhancers from medicinal herbs, we screened their constituents at a concentration of $50 \mu \mathrm{M}$ to evaluate the inhibitory effects on IR-induced A549 cell migration [37]. Figure 2(a) shows the width of the scratch created, which mimics a wound, that was rapidly covered by cells following 10 Gy $\gamma$-irradiation. However, treatment with $50 \mu \mathrm{M}$ of compounds 1-3 decreased the covering rate over the wound area. To quantify cell migration, the width of the scratch created in A549 cells was measured and calculated at 0 and $24 \mathrm{~h}$ after wound creation. As shown in Figure 2(b), all tested compounds significantly suppressed the woundhealing ability of $\gamma$-irradiated A549 cells in comparison with the untreated $\gamma$-irradiated A549 cells. This finding indicated that compounds 1-3 inhibited IR-induced A549 cell migration.

3.3. Cytotoxicity of Compounds 1-3. To investigate whether the inhibitory effects on IR-induced A549 cell migration were actually due to cytotoxicity, the cell viability assay was performed. In this study, the effect of 10 Gy IR on the viability of A549 cells was not tested because it has been reported to have no effect on the viability in A539 cells [38]. The results of the CCK- 8 assay demonstrated that compound $1\left(\mathrm{IC}_{50}\right.$ value at 48 and $72 h=69.94$ and $57.40 \mu \mathrm{M}$, respectively) exhibited cytotoxic effects at $50 \mu \mathrm{M}$, whereas compounds $2-3$ did not ( $\mathrm{IC}_{50}$ values at 48 and $72 h=>200 \mu \mathrm{M}$ ) (Figure 3(a)). These results suggested that the antimigratory activity of compound 1 on $\gamma$-irradiated A549 cells can be partially attributed to its cytotoxicity, whereas compounds 2-3 appear to have inhibitory effects that are independent of cytotoxicity. Next, to determine the noncytotoxic concentration of $1-3$, the cell viability assay was performed with a low concentration of each compound $(2.5$ or $5 \mu \mathrm{M})$. As shown 

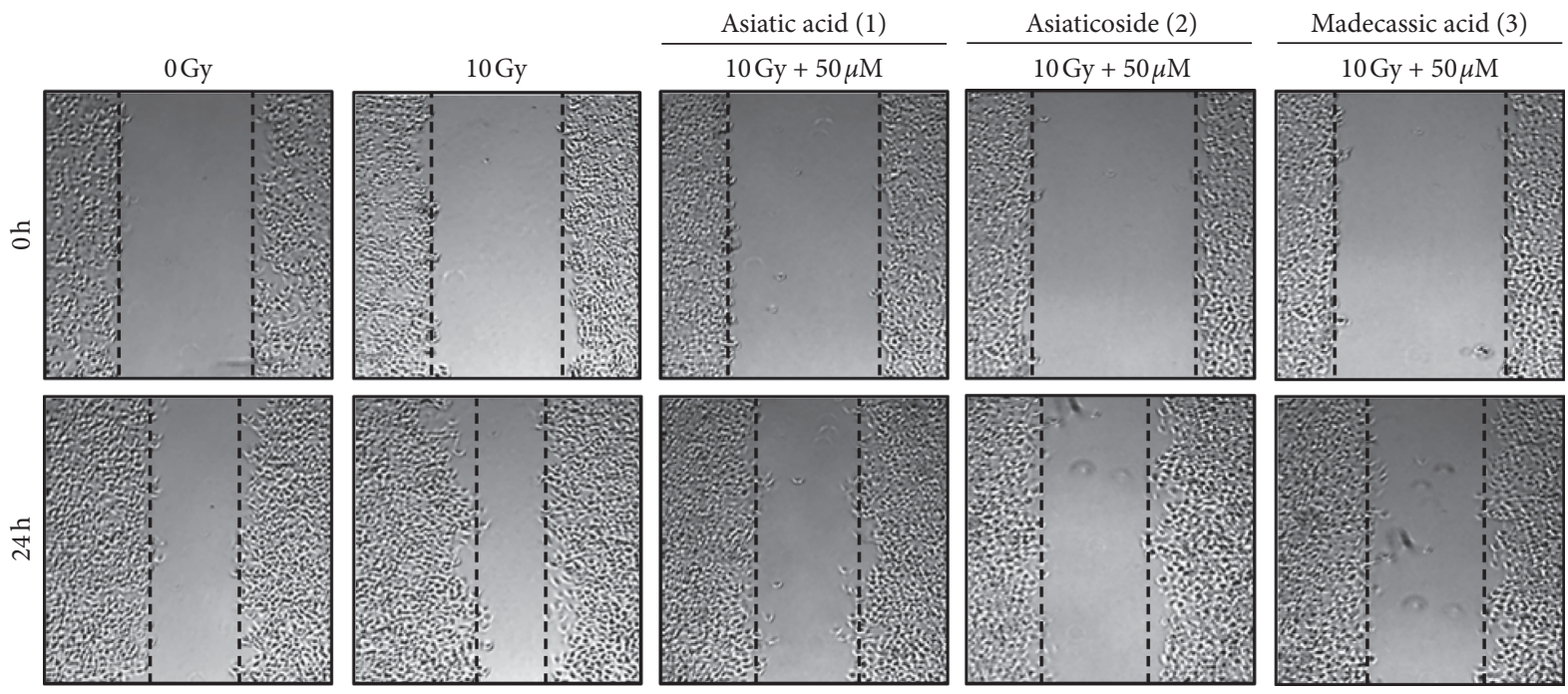

(a)

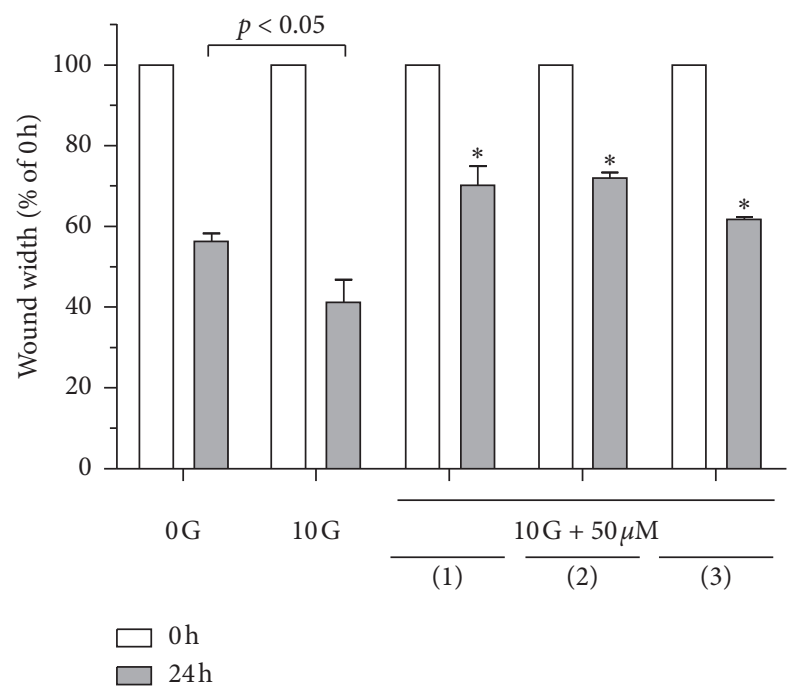

(b)

FIGURE 2: Effects of compounds 1-3 on IR-induced A549 cell migration: (a) wound-healing assay to examine the effects of the indicated compounds $(50 \mu \mathrm{M})$ on the IR-induced migration of A549 cells; (b) quantification of the wound width. The relative wound width was calculated as the ratio of the remaining wound width at a given time point to the original wound width created at $0 \mathrm{~h}$ Data represent the mean $\pm \mathrm{SD}(n=3),{ }^{*} p<0.005$ versus the control (10 Gy IR).

in Figure 3(b), compounds 1-3 did not exhibit cytotoxic effects at these concentrations; thus, further analyses were performed at these concentrations.

3.4. Inhibition of IR-Induced Migration in A549 Cells by Compounds 1-3. The wound-healing assay was performed by treating the cells at the noncytotoxic concentrations of compounds $1-3(2.5$ or $5 \mu \mathrm{M})$ and then exposing to $10 \mathrm{~Gy}$ IR. As shown in Figure 4, compounds 1-3 decreased the covering rate of the width of the scratch created in a dosedependent manner, which was confirmed by quantification of cell migration. These findings indicated that compounds 1-3 can inhibit IR-induced A549 cell migration at a noncytotoxic concentration.

3.5. Inhibition of IR-Induced Invasion in A549 Cells by Compounds 1-3. The transwell assay showed that the invasion of A549 cells was induced by 10 Gy IR, and it 


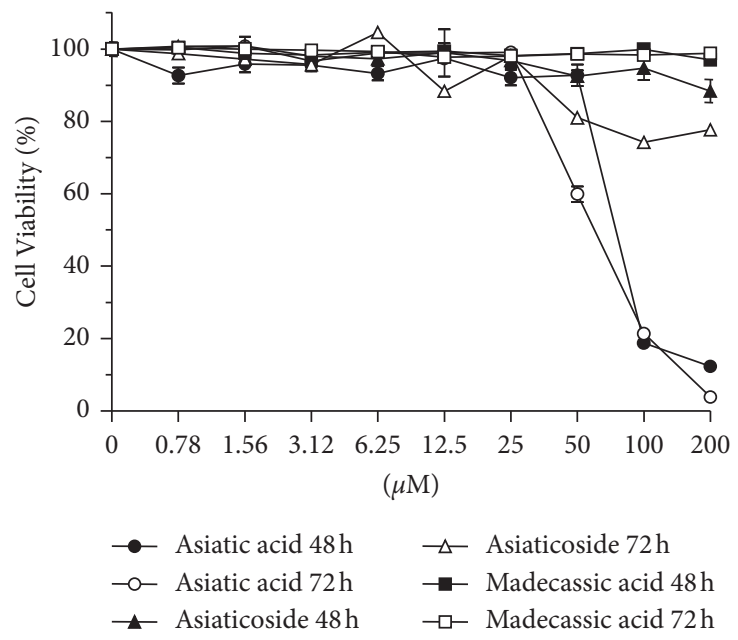

(a)

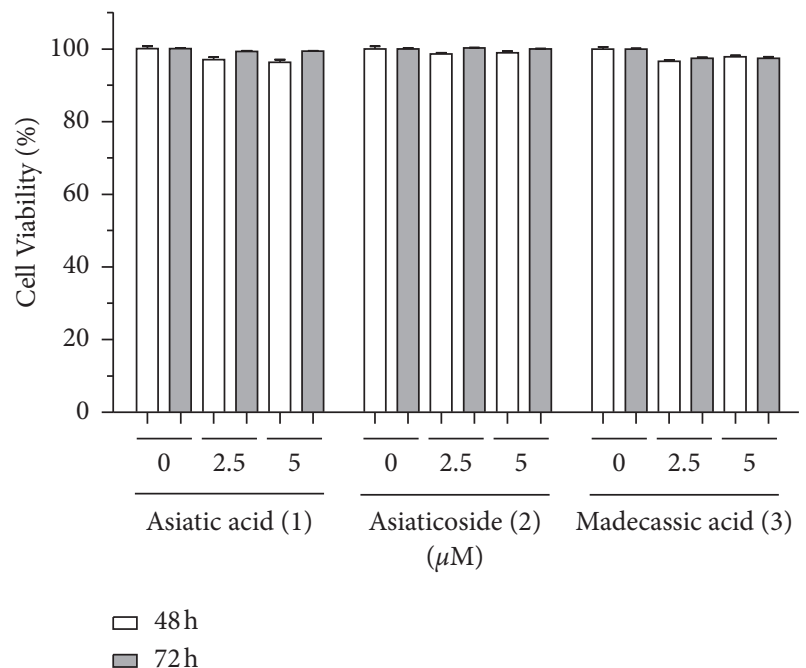

(b)

FIgURE 3: Effect of compounds 1-3 on the viability of A549 cells. Viability of A549 cells $\left(2 \times 10^{3}\right.$ cells/well) was estimated using the CCK-8 assay after treatment with the indicated compounds at (a) $0.78-200 \mu \mathrm{M}$ and (b) 2.5 and $5 \mu \mathrm{M}$ for 48 and $72 \mathrm{~h}$. The values are expressed as mean $\pm S D$ of three independent experiments.

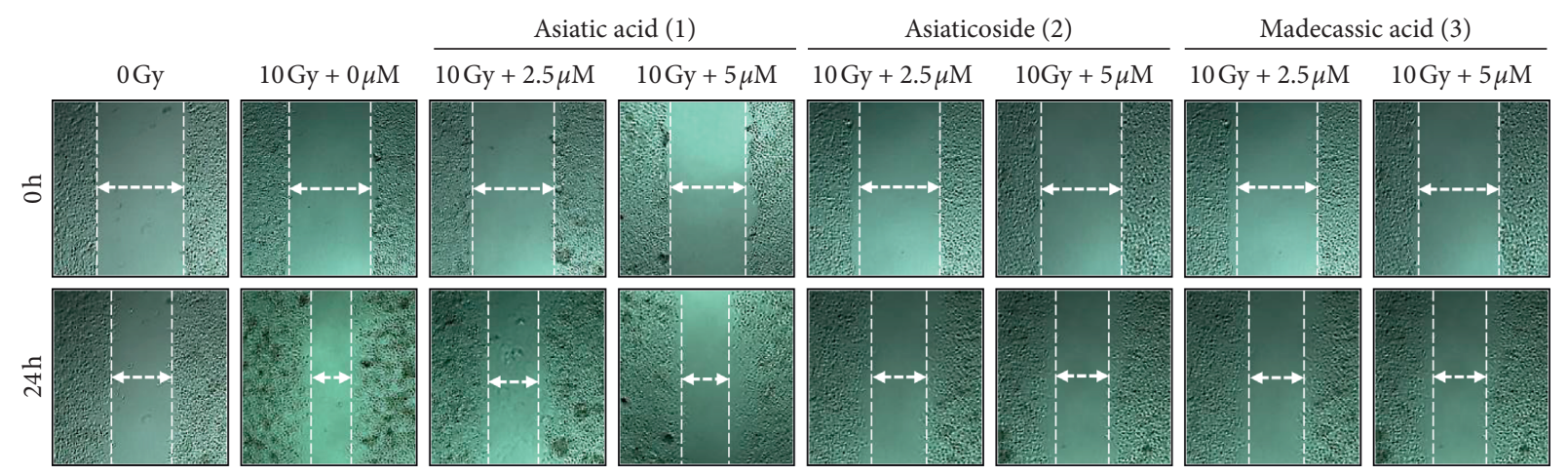

(a)

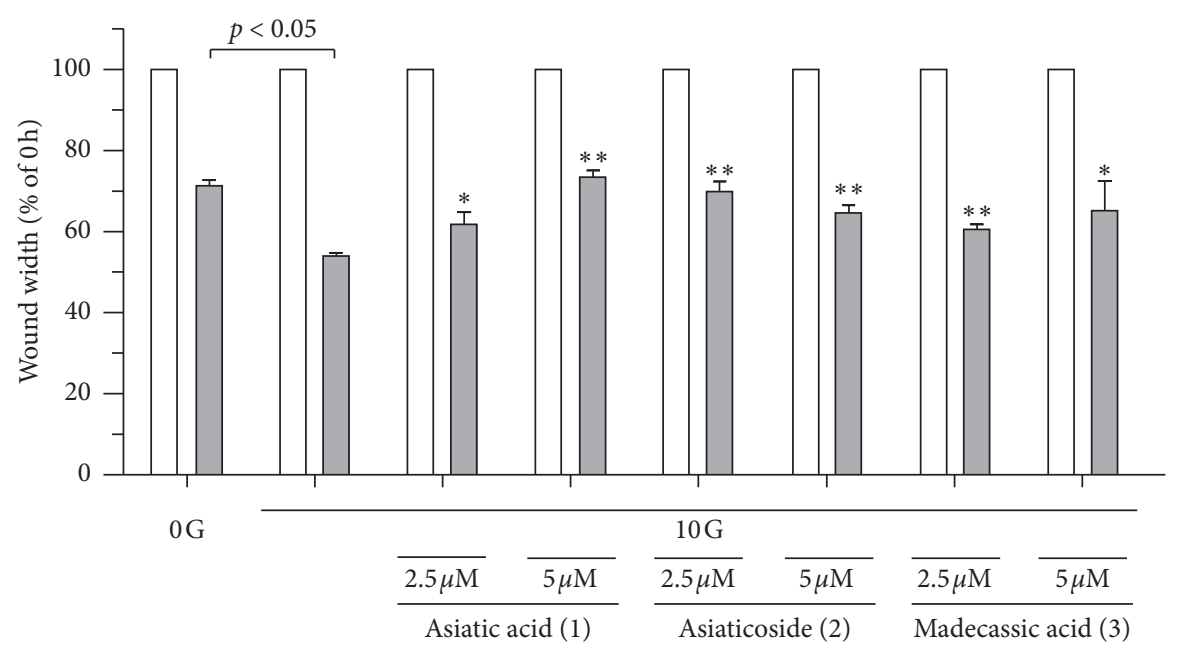

$0 \mathrm{~h}$

$24 \mathrm{~h}$

(b)

FIGURE 4: Effects of compounds 1-3 on IR-induced A549 cell migration: (a) wound-healing assay to examine the effects of the indicated compounds ( 2.5 and $5 \mu \mathrm{M}$ ) on the IR-induced migration of A549 cells; (b) quantification of the wound width. The relative wound width was calculated as the ratio of the remaining wound width at the given time point to that of the original wound width created at $0 \mathrm{~h}$. Data represent the mean $\pm \mathrm{SD}(n=3) ;{ }^{*} p<0.05 ;{ }^{* *} p<0.005$ versus the control (10 Gy IR). 


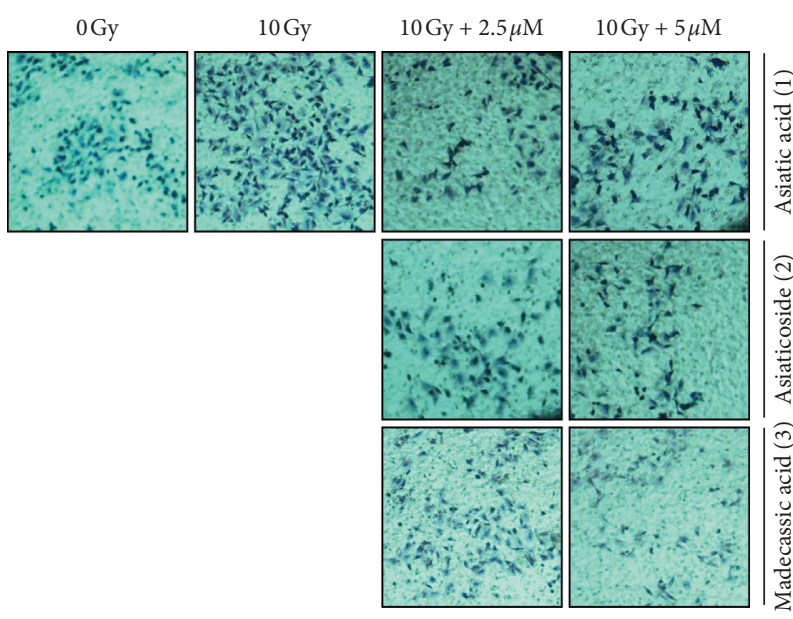

(a)

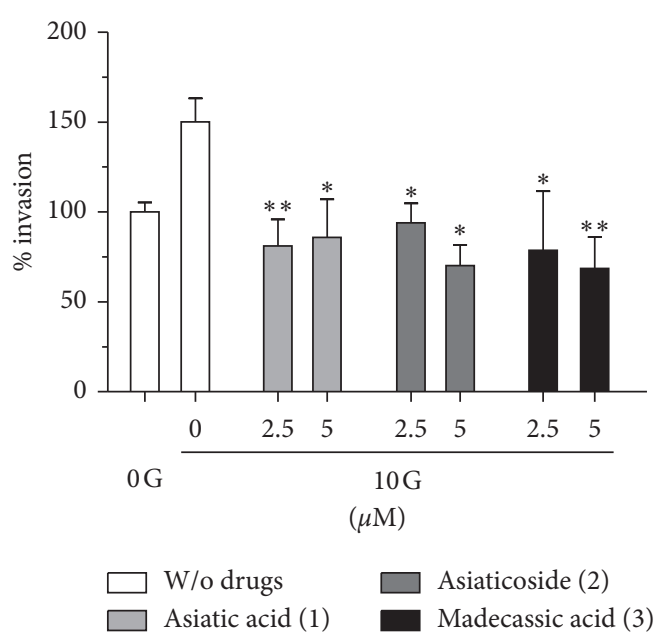

(b)

FIGURE 5: Effects of compounds 1-3 on the IR-induced invasion of A549 cells: (a) cell invasion was assessed using Matrigel-coated transwell plates in nonirradiated and $\gamma$-irradiated A549 cells treated with 2.5 and $5 \mu \mathrm{M}$ compounds $1-3$, respectively; (b) quantification of invasion. The percentage of invasion is represented as the number of cells per field compared with each nonirradiated A549 cell group. Data represent the mean \pm SD $(n=3) ;{ }^{*} p<0.05 ;{ }^{* *} p<0.005$ versus the control.

considerably decreased after treatment with compounds 1-3 (Figure 5(a)). All tested compounds (at the noncytotoxic concentrations) significantly suppressed the invasiveness of $\gamma$-irradiated A549 cells in comparison with that of the untreated $\gamma$-irradiated A549 cells (Figure 5(b)). These results suggested that compounds 1-3 inhibited IR-induced A549 cell invasion at noncytotoxic concentrations.

\section{Conclusions}

In conclusion, we demonstrated that compounds 1-3 isolated from $C$. asiatica with demonstrated anticancer activity can also inhibit the IR-induced migration and invasion of A549 lung cancer cells. These findings suggest that compounds 1-3 might be effective in improving the radiotherapeutic effect in NSCLC. However, further research on the inhibitory mechanisms of these compounds is required.

\section{Data Availability}

The data used to support the findings of this study are available from the corresponding author upon request.

\section{Conflicts of Interest}

The authors declare that there are no conflicts of interest regarding the publication of this paper.

\section{Authors' Contributions}

Ah-Reum Han and Sanghun Lee contributed equally to this study.

\section{Acknowledgments}

This work was supported by grants from the National Research Foundation of Korea (2017R1C1B2006273) and the Korea Atomic Energy Research Institute (KAERI).

\section{References}

[1] S. Singh, A. Gautam, A. Sharma et al., "Centella asiatica (L.): a plant with immense medicinal potential but threatened," International Journal of Pharmaceutical Sciences Review and Research, vol. 4, no. 2, pp. 9-17, 2010.

[2] V. Seevaratnam, P. Banumathi, M. R. Premalatha et al., "Functional properties of Centella asiatica (L.): a review," International Journal of Pharmacy and Pharmaceutical Sciences, vol. 4, pp. 8-14, 2012.

[3] K. Gohil, J. Patel, and A. Gajjar, "Pharmacological review on Centella asiatica: a potential herbal cure-all," Indian Journal of Pharmaceutical Sciences, vol. 72, no. 5, pp. 546-556, 2010.

[4] J. James and I. Dubery, "Pentacyclic triterpenoids from the medicinal herb, Centella asiatica (L.) urban," Molecules, vol. 14, no. 10, pp. 3922-3941, 2009.

[5] N. A. Gajbhiye, J. Makasana, A. Saha, I. Patel, and R. S. Jat, "LC-ESI-MS/MS method for simultaneous determination of triterpenoid glycosides and aglycones in Centella asiatica L," Chromatographia, vol. 79, no. 11-12, pp. 727-739, 2016.

[6] M. F. Nagoor Meeran, S. N. Goyal, K. Suchal et al., "Pharmacological properties, molecular mechanisms, and pharmaceutical development of asiatic acid: a pentacyclic triterpenoid of therapeutic promise," Frontiers in Pharmacology, vol. 9, Article ID 892, 2018.

[7] H. Zhang, M. Zhang, Y. Tao et al., "Madecassic acid inhibits the mouse colon cancer growth by inducing apoptosis and immunomodulation," Journal of B.U.ON, vol. 19, no. 2, pp. 372-376, 2014.

[8] L. Yingchun, W. Huihan, Z. Rong, Z. Guojun, Y. Ying, and L. Zhuogang, "Antitumor activity of asiaticoside against multiple myeloma drug-resistant cancer cells is mediated by autophagy induction, activation of effector caspases, and 
inhibition of cell migration, invasion, and STAT-3 signaling pathway," Medical Science Monitor, vol. 25, pp. 1355-1361, 2019.

[9] F. Bonte, M. Dumas, C. Chaudagne, and A. Meybeck, "Influence of asiatic acid, madecassic acid, and asiaticoside on human collagen i synthesis," Planta Medica, vol. 60, no. 02, pp. 133-135, 1994.

[10] S.-H. Dong, Y.-W. Liu, F. Wei, H.-Z. Tan, and Z.-D. Han, "Asiatic acid ameliorates pulmonary fibrosis induced by bleomycin (BLM) via suppressing pro-fibrotic and inflammatory signaling pathways," Biomedicine \& Pharmacotherapy, vol. 89, pp. 1297-1309, 2017.

[11] J.-W. Lee, H. A. Park, O.-K. Kwon et al., "Asiatic acid inhibits pulmonary inflammation induced by cigarette smoke," International Immunopharmacology, vol. 39, pp. 208-217, 2016.

[12] K. Swapna, V. V. Sathibabu Uddandrao, B. Parim et al., "Effects of asiatic acid, an active constituent in Centella asiatica (L.): restorative perspectives of streptozotocin-nicotinamide induced changes on lipid profile and lipid metabolic enzymes in diabetic rats," Comparative Clinical Pathology, vol. 28, no. 5, pp. 1321-1329, 2019.

[13] Z. Qi, X. Ci, J. Huang et al., "Asiatic acid enhances Nrf2 signaling to protect HepG2 cells from oxidative damage through Akt and ERK activation," Biomedicine \& Pharmacotherapy, vol. 88, pp. 252-259, 2017.

[14] Y. Lu, S. Liu, Y. Wang, D. Wang, J. Gao, and L. Zhu, "Asiatic acid uncouples respiration in isolated mouse liver mitochondria and induces HepG2 cells death," European Journal of Pharmacology, vol. 786, pp. 212-223, 2016.

[15] K. Ternchoocheep, D. Surangkul, and S. Ysothonsreekul, “The recovery and protective effects of asiatic acid on differentiated human neuroblastoma SH-SY5Y cells cytotoxic-induced by cholesterol," Asian Pacific Journal of Tropical Biomedicine, vol. 7, no. 5, pp. 416-420, 2017.

[16] W. Jiang, M. Li, F. He et al., "Neuroprotective effect of asiatic acid against spinal cord injury in rats," Life Sciences, vol. 157, pp. $45-51,2016$.

[17] R. Subban, A. Veerakumar, R. Manimaran, K. M. Hashim, and I. Balachandran, "Two new flavonoids from Centella asiatica (linn.)," Journal of Natural Medicines, vol. 62, no. 3, pp. 369-373, 2008.

[18] R. Srivastava, Y. N. Shukla, and S. Kumar, "Chemistry and pharmacology of Centella asiatica: a review," Journal of Medicinal and Aromatic Plants, vol. 19, pp. 1049-1056, 1997.

[19] S. C. Francis and M. T. Thomas, "Essential oil profiling of centella asiatica (L.) Urb.-A medicinally important herb," South Indian Journal of Biological Sciences, vol. 2, no. 1, pp. 169-173, 2016.

[20] R. L. Siegel, K. D. Miller, and A. Jemal, "Cancer statistics," A Cancer Journal for Clinicians, vol. 69, no. 1, pp. 7-34, 2019.

[21] C. Zappa and S. A. Mousa, "Non-small cell lung cancer: current treatment and future advances," Translational Lung Cancer Research, vol. 5, no. 3, pp. 288-300, 2016.

[22] J. Ferlay, I. Soerjomataram, R. Dikshit et al., "Cancer incidence and mortality worldwide: sources, methods and major patterns in GLOBOCAN 2012," International Journal of Cancer, vol. 136, no. 5, pp. E359-E386, 2015.

[23] H. Lemjabbar-Alaoui, O. U. Hassan, Y. W. Yang et al., "Lung cancer: biology and treatment options," Biochimica et Biophysica Acta, vol. 1856, no. 2, pp. 189-210, 2015.

[24] M. Vilalta, M. Rafat, and E. E. Graves, "Effects of radiation on metastasis and tumor cell migration," Cellular and Molecular Life Sciences, vol. 73, no. 16, pp. 2999-3007, 2016.
[25] J. N. Ho, G. Y. Kang, S. S. Lee et al., "Bcl-XL and STAT3 mediate malignant actions of gamma-irradiation in lung cancer cells," Cancer Science, vol. 101, no. 6, pp. 1417-1423, 2010.

[26] C. Moncharmont, A. Levy, J. B. Guy et al., "Radiation-enhanced cell migration/invasion process: a review," Critical Reviews in Oncology/Hematology, vol. 92, no. 2, pp. 133-142, 2014.

[27] K. Camphausen, M. A. Moses, W. D. Beecken et al., "Radiation therapy to a primary tumor accelerates metastatic growth in mice," Cancer Science, vol. 61, no. 5, pp. 2207-2211, 2001.

[28] L. Tang, F. Wei, Y. Wu et al., "Role of metabolism in cancer cell radioresistance and radiosensitization methods," Journal of Experimental and Clinical Cancer Research, vol. 37, no. 1, Article ID 87, 2018.

[29] T. D. Babu, G. Kuttan, and J. Padikkala, "Cytotoxic and antitumour properties of certain taxa of umbelliferae with special reference to Centella asiatica (L.) urban," Journal of Ethnopharmacology, vol. 48, no. 1, pp. 53-57, 1995.

[30] C. H. Jung, A. R. Han, H. J. Chung et al., "Linarin inhibits radiation-induced cancer invasion by downregulating MMP9 expression via the suppression of NF- $\kappa \mathrm{B}$ activation in human non-small-cell lung cancer A549," Natural Product Research, vol. 33, no. 24, pp. 3582-3586, 2019.

[31] C. H. Jung, E. M. Kim, J. K. Park et al., "Bmal1 suppresses cancer cell invasion by blocking the phosphoinositide 3-kinase-Akt-MMP-2 signaling pathway," Oncology Reports, vol. 29, no. 6, pp. 2109-2113, 2013.

[32] U. Anand, N. Jacobo-Herrera, A. Altemimi et al., "A comprehensive review on medicinal plants as antimicrobial therapeutics: potential avenues of biocompatible drug discovery," Metabolites, vol. 9, no. 11, Article ID 258, 2019.

[33] J. Sharifi-Rad, A. Ozleyen, T. Boyunegmez Tumer et al., "Natural products and synthetic analogs as a source of antitumor drugs," Biomolecules, vol. 9, no. 11, Article ID 679, 2019.

[34] I. L. Acebey-Castellon, L. Voutquenne-Nazabadioko, H. Doan Thi Mai et al., "Triterpenoid saponins from Symplocos lancifolia," Journal of Natural Products, vol. 74, no. 2, pp. 163-168, 2011.

[35] Q. Du, G. Jerz, P. Chen et al., "Preparation of ursane triterpenoids from Centella asiatica using high speed countercurrent chromatography with step-gradient elution," Journal of Liquid Chromatography \& Related Technologies, vol. 27, no. 14, pp. 2201-2215, 2004.

[36] D. Monti, A. Candido, M. M. C. Silva et al., "Biocatalyzed generation of molecular diversity: selective modification of the saponin asiaticoside," Advanced Synthesis \& Catalysis, vol. 347, pp. 1168-1174, 2005.

[37] S. H. Lee, A.-R. Han, U. Kang et al., "Inhibitory effects of furanocoumarins from the roots of Angelica dahurica on ionizing radiation-induced migration of A549 human nonsmall cell lung cancer cells," Natural Product Communications, vol. 15, pp. 1-6, 2020.

[38] A. R. Kang, J. H. Cho, N. G. Lee et al., "RIP1 is a novel component of $\gamma$-ionizing radiation-induced invasion of nonsmall cell lung cancer cells," International Journal of Molecular Sciences, vol. 21, no. 13, p. 4584, 2020. 